\title{
PEMASARAN KENTANG DI DESA MAKAARUYEN, KECAMATAN MODOINDING
}

\author{
Christy Militia Linelejan \\ Ribka M. Kumaat \\ Juliana R. Mandey
}

\begin{abstract}
The study aims to knowing the marketing of potatoes in Makaaruyen Village, Modoinding Sub District. The data used are primary data and secondary data. Primary data were obtained through a list of qusions that had been provided, while secondary data obtained from BP3K office Modoinding district and village office Makaaruyen Modoinding district. Sampling method is done by simple random sampling for sample of farmers and snowball sampling method for marketing agencies, where the simple is obtained based on information from the first respondent then traced to the next respondent. Data is presented in numerical form and analyzed quantitatively. The consept of measurement of variables used are costs consisting of packing, sortir fees, freight costs, loading and unloading costs, depreciation costs and retribution fees. The research result showed that there was five channel of potatoes in Makaaruyen village, Modoinding Sub District. The marketing institutions involved include village collecting, sub district collecting, sub district traders, out of town merchants and retailers. Marketing activities in the Makaaruyen Village of the Modoinding Sub District is an activity that begins with partners and cooperation between farmers and marketing agencies involved in potato marketing activities.
\end{abstract}

Keywords: marketing of potatoe, Village Makaaruyen, Modoinding Sub District

Penelitian ini bertujuan untuk mengetahui pemasaran kentang di Desa Makaaruyen Kecamatan Modoinding. Data yang digunakan yaitu data primer dan data sekunder. Data primer diperoleh melalui daftar pertanyaan yang telah disiapkan sedangkan data sekunder diperoleh dari Kantor BP3K Kecamatan Modoinding dan Kantor Desa Makaaruyen Kecamatan Modoinding. Metode pengambilan sampel dilakukan dengan cara Simple Random Sampling atau secara acak sederhana untuk sampel petani dan metode Snowball Sampling untuk lembaga pemasaran, dimana sampel diperoleh berdasarkan informasi dari responden pertama kemudian ditelusuri ke responden berikutnya. Data disajikan dalam bentuk angka dan dianalis secara kuantitatif. Konsep pengukuran variabel yang digunakan adalah biaya yang terdiri dari biaya pengepakan, biaya sortir, biaya pengangkutan, biaya bongkar muat, biaya penyimpanan, biaya penyusutan dan biaya retribusi. Hasil penelitian ini menunjukan bahwa Saluran pemasaran yang terjadi di Desa Makaaruyen Kecamatan Modoinding terdiri dari 5 saluran pemasaran. Lembaga pemasaran yang terlibat diantaranya pedagang pengumpul desa, pedagang pengumpul kecamatan, pedagang besar kecamatan, pedagang besar luar kota dan pedagang pengecer. Kegiatan pemasaran di Desa Makaaruyen Kecamatan Modoinding merupakan aktivitas yang dimulai dari mitra serta kerja sama antar petani dan lembaga pemasaran yang terlibat pada kegiatan pemasaran kentang.

Kata kunci: pemasaran kentang, Desa Makaaruyen, Kecamatan Modoinding 


\section{PENDAHULUAN}

\section{Latar Belakang}

Sektor pertanian merupakan sektor strategis yang memiliki peranan penting dalam pembangunan nasional yang mengacu pada perekonomian di Indonesia. Hal ini dapat dilihat dari kemampuan sektor pertanian berkontribusi pada Produk Domestik Bruto (PDB), dalam penyerapan tenaga kerja, sumber ketersediaan pangan dan penciptaan kesempatan kerja atau usaha dalam peningkatan pendapatan masyarakat serta sebagai sumber perolehan devisa (Nadhawatunnaja, 2008). Tanaman hortikultura merupakan bagian dari sektor pertanian yang dapat memberikan kontribusi cukup besar dalam peningkatan pendapatan petani dan pemenuhan gizi keluarga. Salah satu tanaman hortikultura yang memiliki peluang untuk memenuhi kebutuhan pangan adalah kentang. Tanaman kentang adalah komoditas yang memiliki potensi dan prospek yang baik dalam rangka mewujudkan ketahanan pangan yang berkelanjutan (Setiadi, 2009).

Kentang layak untuk diusahakan dan dikembangkan karena nilai ekonomisnya tinggi dan permintaan kentang terus meningkat seiring dengan semakin meluasnya pendayagunaan kentang untuk berbagai keperluan, sebagai kentang konsumsi maupun kentang industry. Proses pendistribusian kentang kepada konsumen dilakukan melalui proses pemasaran untuk menjembatani berpindahnya kentang dari sisi produksi ke sisi konsumsi. Pemasaran kentang yang baik akan mengalirkan kentang dari petani ke konsumen dan memberikan indikasi tentang perubahan penawaran permintaan kentang kepada petani (Nurulita, 2011). Desa Makaaruyen merupakan salah satu desa yang menjadi sentra produksi kentang di Sulawesi Utara dilihat dari data luas panen, luas tanam dan produksi kentang di Kecamatan Modoinding. Berikut ini tabel yang menunjukan luas tanam, luas panen dan produksi kentang di Kecamatan Modoinding Tahun 2015.
Tabel 1. Luas Tanam, Luas Panen dan Produksi Kentang per Desa di Kecamatan Modoinding Tahun 2015

\begin{tabular}{lcccc}
\hline \multicolumn{1}{c}{ Desa } & $\begin{array}{c}\text { Luas } \\
\text { Tanam } \\
\text { (Ha) }\end{array}$ & $\begin{array}{c}\text { Luas } \\
\text { Panen } \\
\text { (Ha) }\end{array}$ & $\begin{array}{c}\text { Produktifitas } \\
\text { (Ton) }\end{array}$ & $\begin{array}{c}\text { Total } \\
\text { Produksi }\end{array}$ \\
\hline Mokobang & 25 & 20 & 20 & 400 \\
Wulurmaatus & 26 & 30 & 20 & 600 \\
Palelon & 25 & 26 & 20 & 520 \\
Makaaruyen & 29 & 34 & 20 & 680 \\
Pinasungkulan & 26 & 33 & 20 & 660 \\
Pinasungkula & & & & \\
n Utara & 27 & 30 & 20 & 600 \\
Linelean & 28 & 31 & 20 & 620 \\
Sinisir & 25 & 32 & 20 & 520 \\
Kakenturan & 25 & 26 & & \\
Kakenturan & & & 20 & 560 \\
Barat & 20 & 28 & $\mathbf{5 8 0 0}$ \\
\hline Jumlah & $\mathbf{2 5 6}$ & $\mathbf{2 9 0}$ &
\end{tabular}

Tabel 1 menunjukkan bahwa jumlah produksi kentang terbanyak terletak di Desa Makaaruyen. Produksi kentang di Desa Makaaruyen Kecamatan Modoinding tidak hanya dipasarkan diwilayah Modoinding, melainkan juga dipasarkan diluar Kecamatan Modoinding seperti pasar Kotamobagu, pasar Langowan, pasar Bersehati dan pasar Karombasan. Pemasaran Kentang di Desa Makaaruyen dilakukan oleh pedagang dari luar desa Makaaruyen dan oleh pedagang dari dalam desa Makaaruyen. Permasalahan yang sering dihadapi dalam mewujudkan pemasaran kentang yang baik adalah tinggi rendahnya tingkat harga yang diterima petani erat kaitannya dengan pola pemasaran yang terbentuk dan besarnya marjin pemasaran, sehingga untuk meningkatkan pemasaran kentang dapat dicapai apabila pola pemasaran dan penyebab tingginya marjin pemasaran diketahui (Widayanti, 2008). Untuk memperoleh nilai jual yang baik, maka mekanisme pemasaran harus berjalan dengan baik pula sesuai tujuan yang akan dicapai agar semua pihak yang terlibat diuntungkan.

Bagi konsumen tingkat harga yang tinggi merupakan beban. Bagi produsen keuntungan dapat diterima rendah karena tingkat harga yang diterima rendah. Pendapatan petani sangat dipengaruhi oleh pemasaran hasil produksinya dan harga yang berlaku (Soekartawi, 2002).

\section{Rumusan Masalah}

Rumusan masalah dalam penelitian ini yaitu Bagaimana pemasaran kentang di Desa Makaaruyen Kecamatan Modoinding. 


\section{Tujuan Penelitian}

Tujuan penelitian ini yaitu: Tujuan penelitian ini yaitu untuk mengetahui pemasaran kentang di Desa Makaaruyen Kecamatan Modinding.

\section{Manfaat Penelitian}

Manfaat dari penelitian ini yaitu untuk memberikan informasi tentang pemasaran kentang di Desa Makaaruyen Kecamatan Modinding.

\section{METODOLOGI PENELITIAN}

\section{Waktu dan Tempat Penelitian}

Penelitian ini dilakukan selama tiga bulan yaitu dari bulan Juni sampai Agustus tahun 2017. Tempat penelitian dilaksanakan di Desa Makaaruyen Kecamatan Modoinding.

\section{Metode Pengumpulan Data}

Data yang digunakan dalam penelitian ini adalah data primer dan data sekunder. Data primer diperoleh melalui metode wawancara dengan menggunakan daftar pertanyaan (kusioner) kepada petani, pedagang pengumpul desa, pedagang pengumpul kecamatan, pedagang besar dan pedagang pengecer. Data yang diambil adalah identitas responden, biaya pemasaran kentang dan proses pemasaran kentang. Sedangkan data sekunder diperoleh dari instansi-instansi yang terkait dalam penelitian ini seperti BP3K Kecamatan Modoinding dan Kantor Kecamatan Modoinding. Data yang diambil adalah luas lahan dan jumlah produksi kentang dari setiap desa di Kecamatan Modoinding.

\section{Metode Pengambilan Sampel}

Penentuan lokasi penelitian dilakukan secara tunjuk langsung atau sengaja (Purposive Sampling) yaitu di desa Makaaruyen Kecamatan Modoinding. Pengambilan sampel petani dilakukan dengan menggunakan metode simple random sampling atau secara acak sederhana dengan jumlah petani yang dijadikan sampel sebanyak 40 orang petani yang berusahatani kentang. Metode pengambilan sampel lembaga pemasaran dilakukan dengan cara Snowball Sampling, dimana sampel diperoleh berdasarkan informasi dari responden pertama yaitu petani di Desa Makaaruyen Kecamatan Modoinding selanjutnya ditelusuri hingga ketingkat konsumen akhir.

\section{Konsep dan Pengukuran Variabel}

Adapun variabel yang diukur dalam penelitian ini adalah :

1. Biaya Pengepakan untuk tenaga kerja mengepak kentang $(\mathrm{Rp} / \mathrm{Kg})$
2. Biaya Pengemasan untuk pembelian karung dan kantong plastik kentang $(\mathrm{Rp} / \mathrm{Kg})$

3. Biaya Sortir untuk tenaga kerja pembersihan dan penggolongan kentang $(\mathrm{Rp} / \mathrm{Kg})$

4. Biaya Pengangkutan untuk transportasi atau ongkos kentang dari produsen ke konsumen $(\mathrm{Rp} / \mathrm{Kg})$

5. Biaya Bongkar Muat untuk tenaga kerja pemindahan kentang yang ada dimobil dan yang ada dikapal $(\mathrm{Rp} / \mathrm{Kg})$

6. Biaya Penyusutan untuk sewa alat gerobak mengangkut kentang $(\mathrm{Rp} / \mathrm{Kg})$

7. Biaya Penyimpanan untuk gedung penampungan kentang $(\mathrm{Rp} / \mathrm{Kg})$

8. Biaya Retribusi untuk iuran dipasar sebgai balas jasa atas pemberian izin oleh pemerintah kepada lembaga pemasaran $(\mathrm{Rp} / \mathrm{Kg})$.

\section{Metode Analisis Data}

Penelitian ini menggunakan metode analisis kuantitatif untuk mengetahui keuntungan pemasaran, marjin pemasaran dan farmer's share di setiap saluran pemasaran.

1. Keuntungan Pemasaran

$\mathrm{Kpn}=\mathrm{Psn}-\mathrm{Pbn}-\mathrm{Bpn}$

Dimana :

Kpn: Keuntungan lembaga pemasaran

Psn: Harga jual kentang lembaga pemasaran

Pbn: Harga beli kentang lembaga pemasaran

Bpn: Biaya pemasaran kentang lembaga pemasaran

2. Marjin Pemasaran

$\mathrm{Mp}=\mathrm{Pr}-\mathrm{Pf}$

Dimana :

Mp: Marjin Pemasaran Kentang

Pr: Harga kentang di tingkat konsumen

Pf: Harga kentang di tingkat petani

3. Farmer's Share

$\mathrm{F}=\mathrm{Pf} / \mathrm{Pr} \times 100 \%$

Dimana :

F: Bagian yang diterima petani

Pf: Harga kentang ditingkat petani

Pr: Harga kentang ditingkat konsumen.

\section{HASIL DAN PEMBAHASAN}

\section{Deskripsi Daerah Penelitian}

\section{Keadaan Geografis Penelitian}

Desa Makaaruyen adalah salah satu desa yang ada di Kecamatan Modoinding. Kecamatan Modoinding berada di Kabupaten Minahasa 
Selatan Provinsi Sulawesi Utara, yang terdiri dari 10 desa dengan luas wilayah $6.640 \mathrm{Ha}$ dan merupakan wilayah yang paling tinggi karena seluruh desanya berada di ketinggian $\pm 1100 \mathrm{~m}$ diatas permukaan laut. Batas-batas wilayah Kecamatan Modoinding adalah sebagai berikut :

1. Sebelah Utara berbatasan dengan Kecamatan Maesaan

2. Sebelah Selatan berbatasan dengan Kabupaten Bolaang Mongondow

3. Sebelah Timur berbatasan dengan Kabupaten Bolaang Mongondow

4. Sebelah Barat berbatasan dengan Kabupaten Bolaang Mongondow.

\section{Jumlah Penduduk}

Penduduk di Kecamatan Modoinding berjumlah 12.729 jiwa, yang mencakup penduduk yang bertempat tinggal tetap dan tidak tetap. Desa Makaaruyen merupakan desa yang paling banyak jumlah penduduknya yakni 1.654 jiwa, dengan jumlah penduduk laki-laki 778 jiwa dan jumlah penduduk perempuan 876 jiwa. Keluarga di Kecamatan Modoinding berjumlah 3.948 KK.

\section{Mata Pencaharian}

Tingkat perekonomian di Desa Makaaruyen Kecamatan Modoinding umumnya ditentukan oleh sektor pertanian.Sebagai mata pencaharian adalah bertani seperti tanaman hortikultura yaitu kentang.

\section{Karakteristik Responden Petani}

\section{Umur Petani}

Umur petani akan mempengaruhi produktivitas kerja atau perannya dalam pengambilan keputusan dari berbagai alternatif pekerjaan yang dilakukan. Umur petani memiliki hubungan dengan kemampuan petani dalam bekerja. Jika ditinjau dari segi fisik, semakin tua umur seseorang setelah melewati batas umur tertentu, maka semakin berkurang kemampuan untuk bekerja. Umur petani responden menurut hasil penelitian dapat dilihat dalam Tabel 2.

\begin{tabular}{|c|c|c|c|}
\hline Tabel & $\begin{array}{l}\text { 2. Jumlah Presentase } \\
\text { Kelompok Umur }\end{array}$ & Petani Responden & Berdasarkan \\
\hline No & $\begin{array}{c}\text { Umur } \\
\text { (Tahun) }\end{array}$ & $\begin{array}{c}\text { Jumlah } \\
\text { Responden }\end{array}$ & $\begin{array}{c}\text { Presentase } \\
(\%)\end{array}$ \\
\hline 1 & $20-30$ & 8 & 20,00 \\
\hline 2 & $31-40$ & 11 & 27,50 \\
\hline 3 & $41-50$ & 11 & 27,50 \\
\hline 4 & $52-60$ & 10 & 25,00 \\
\hline & Total & 40 & 100 \\
\hline
\end{tabular}

Tabel 2 menunjukkan bahwa petani responden pada kelompok umur $<40$ sebanyak 19 orang petani atau $47,50 \%$ dari petani responden dan untuk $>40$ sebanyak 21 orang petani atau 52,50\% dari petani responden. Berdasarakan hasil penelitian, dapat dikatakan bahwa petani yang berada di Desa Makaaruyen Kecamatan Modoinding berada pada umur produktif, sehingga diharapkan petani mampu mengembangkan usahatani kentang untuk meningkatkan penerimaan usahataninya.

\section{Tingkat Pendidikan}

Pendidikan mempunyai peran penting dalam proses meningkatkan kualitas dan kemampuan individu. Pendidikan seseorang sangat mempengaruhi cara berfikir dan bertindak sehingga dalam melaksanakan suatu kegiatan dapat mempertimbangkan berbagai hal yang dapat menguntungkan, merugikan dan dapat menentukan alternatif kegiatan yang dilakukan. Tingkat pendidikan responden petani dapat dilihat pada Tabel 3.

\begin{tabular}{|c|c|c|c|}
\hline Tab & \multicolumn{2}{|c|}{$\begin{array}{r}\text { Jumlah Presentase } P \\
\text { Kelompok Umur }\end{array}$} & \multirow{2}{*}{$\begin{array}{c}\text { Berdasarka } \\
\begin{array}{c}\text { Presentase } \\
(\%)\end{array}\end{array}$} \\
\hline No & $\begin{array}{c}\text { Tingkat } \\
\text { Pendidikan }\end{array}$ & $\begin{array}{c}\text { Jumlah } \\
\text { Responden }\end{array}$ & \\
\hline 1 & SD & 8 & 20,00 \\
\hline 2 & SMP & 18 & 45,00 \\
\hline 3 & SMA & 12 & 30,00 \\
\hline 4 & S1 & 2 & 5,00 \\
\hline & Total & 40 & 100 \\
\hline
\end{tabular}

Tabel 3 menunjukkan bahwa tingkat pendidikan petani tertinggi berada pada tingkat pendidikan SMP dengan jumlah petani responden 18 orang sedangkan tingkat SMA yaitu 30,00\% dengan jumlah petani responden 12 orang kemudian pada tingkat SD yaitu 20,00 $\%$ dengan jumlah petani responden 8 orang dan tingkat S1 yaitu $5,00 \%$ dengan jumlah petani responden dua orang. Maka dapat dikatakan bahwa tingkat pendidikan petani kentang di Desa Makaaruyen Kecamatan Modoinding cukup relatif, karena sebagian besar petani responden pernah menempuh pendidikan meskipun berada pada tingkat yang berbeda.

\section{Pengalaman Bertani}

Keberhasilan usahatani kentang tidak terlepas dari pengalaman petani dalam berusahatani kentang. Pengalaman merupakan refrensi bagi petani dalam pengambilan keputusan dimasa yang akan datang, baik dalam hal usahatani maupun pemasarannya. Data mengenai lamanya usahatani kentang di Desa Makaaruyen Kecamatan Modoiniding dapat dilihat pada Tabel 4. 
Tabel 4. Jumlah dan Presentase Pengalaman Usahatani Kentang Petani Reseponden

\begin{tabular}{|c|c|c|c|}
\hline No & $\begin{array}{c}\text { Lama Usahatani Kentang } \\
\text { (Tahun) }\end{array}$ & $\begin{array}{c}\text { Jumlah } \\
\text { Responden }\end{array}$ & $\begin{array}{l}\text { Presentase } \\
(\%)\end{array}$ \\
\hline 1 & $5-15$ & 21 & 52,50 \\
\hline 2 & $16-26$ & 15 & 37,50 \\
\hline 3 & $\geq 26$ & 4 & 10,00 \\
\hline Tot: & & 40 & 100 \\
\hline
\end{tabular}

Sumber : Data Primer yang Diolah, 2017

Berdasarkan Tabel 4 dapat diketahui bahwa sebagian besar petani telah menjalankan usaha tani kentang selama 5-15 tahun yaitu sebanyak 21 petani atau 52,50\% sedangkan pengalaman usaha tani $\geq 26$ tahun telah dilakukan oleh empat orang petani responden atau $10,00 \%$ dan untuk 15 orang petani dengan presentase $37,50 \%$ telah menjalankan usaha tani selama 16-26 tahun. Sehingga apat dilihat bahwa lamanya petani menjalankan usahatani kentang, menunjukan bahwa usahatani kentang di Desa Makaaruyen Kecamatan Modoinding tetap berjalan dan bertaham walaupun harga jual kentang yang tidak stabil.

\section{Karakteristik Responden Lembaga Pemasaran kentang}

\section{Tingkat Umur}

Faktor umur dan kondisi fisik pedagang berpengaruh pada aktivitas pemasaran kentang yang dijalankannya karena pada umumnya pedagang terlibat secara langsung baik selama proses pembelian maupun penjualan kentang sehingga dibutuhkan pembelian kentang dengan mendatangi petani secara langsung dan mengumpulkannya kemudian dijual kepedagang luar kota atau kepedagang pengecer. Berdasarkan hasil penelitian, umur pedagang pengumpul desa yang pertama yaitu 29 tahun dan responden yang kedua berumur 47 tahun. Pedagang pengumpul kecamatan yang ada di Desa Makaaruyen Kecamatan Modoinding berjumlah 2 orang yang berada pada usia 35-47 tahun.Umur pedagang besar kecamatan yaitu 49 tahun. Pedagang pengecer dalam penelitian ini berjumlah 13 orang yang berada pada usia 32-53 tahun. Dapat dilihat bahwa sebagian besar pedagang berada pada usia produktif sehingga pedagang masih mampu bekerja dengan baik, didukung dengan fisik yang masih kuat dalam melaksanakan peran sebagai penyalur pemasaran kentang kepada konsumen.

\section{Tingkat Pendidikan}

$$
\text { Faktor pendidikan mempengaruhi }
$$

pengambilan keputusan yang dilakukan oleh pedagang dalam memasarkan kentangnya. Pendidikan yang ditempuh mempermudah pedagang kentang dalam menjalankan usahanya terutama dalam perhitungan pendapatan serta penyerapan tekonologi baru yang dapat menunjang usahanya. Berdasarkan hasil penelitian, tingkat pendidikan yang ditempuh oleh pedagang pengumpul desa dan pedagang pengumpul kecamatan yaitu dua orang tamat SMP dan dua orang tamat SMA.Pedagang besar kecamatan dan pedagang besar pelabuhan Bitung memiliki tingkat pendidikan yang sama yaitu tamat SMA. Tingkat pendidikan pedagang pengecer adalah tamat SD sebanyak enam orang, tamat SMP tiga orang dan tamat SMA empat orang.Seluruh responden telah mengikuti pendidikan formal dengan tingkat pendidikan yang berbeda yaitu tamat SD, SMP dan SMA.Sehingga pedagang dapat mengikuti informasi pasar untuk harga kentang dengan baik.

\section{Pengalaman Berusaha}

Pengalaman yang dimiliki pedagang dapat terlihat dari berapa lama mereka menjalankan usahanya dalam memasarkan kentang. Pengalaman usaha membantu pedagang dalam mengamati dan memprediksi keadaan pasar sehingga pedagang dapat menentukan strategi pemasaran yang akan dijalankan. Pengalaman dan lamanya dalam menekuni profesi sebagai pedagang pengumpul desa dan pedagang pengumpul kecamatan yaitu $>5$ tahun untuk empat orang responden. Pengalaman berusaha dari pedagang besar kecamatan dan pedagang besar pelabuhan Bitung yang sudah menekuni pekerjaan ini yaitu selama $>15$ tahun untuk kedua responden pedagang besar. Sebanyak tujuh orang pengecer telah menekuni pekerjaan ini selama $>15$ tahun dan yang menekuni pekerjaan ini selama $>20$ tahun yaitu sebanyak 6 orang pedagang pengecer.

\section{Pemasaran Kentang di Desa Makaaruyen Kecamatan Modoinding}

Pemasaran kentang merupakan kegiatan penyampaian komoditi kentang dari petani, pedagang pengumpul desa, pedagang pengumpul kecamatan, pedagang besar kecamatan, pedagang besar luar kota, pedagang pengecer dan konsumen. Masing-masing lembaga pemasaran mempunyai peranan penting dalam pemasaran kentang.

1. Petani

Petani merupakan produsen kentang yang mengawali pemasaran kentang di Desa Makaaruyen Kecamatan Modoinding. Petani ini berperan penting pada pemasaran kentang karena kualitas dan kuantitas pasokan kentang sangat ditentukan olehnya.Hasil penelitian menunjukkan bahwa ada tujuh orang petani yang menjual kentang pada pedagang pengumpul desa, sepuluh orang petani pada pedagang pengumpul kecamatan dan dua puluh tiga orang petani kepada pedagang besar. 
2. Pedagang Pengumpul

Pedagang pengumpul merupakan pedagang yang melakukan aktivitas membeli kentang dari petani untuk dijual kepada pedagang pengecer. Hasil penelitian menunjukkan bahwa ada enam orang pedagang pengumpul, dimana satu orang pedagang pengumpul desa melakukan mitra dengan pedagang pengecer yang ada di pasar Kotamobagu dan satu orang di pasar Langowan sedangkan dua orang pedagang pengumpul kecamatan membeli kentang dari petani untuk dibawah ke pedagang pengecer yang ada dipasar Bersehati dan Karombasan dan ada satu pengumpul besar di kecamatan yang membawah kentang kepada satu orang pedagang besar di pelabuhan Bitung.

3. Pedagang Pengecer

Pedagang pengecer merupakan pedagang yang membeli kentang dari pedagang pengumpul desa dan pedagang pengumpul kecamatan untuk dijual kepada konsumen. Hasil penelitian menunjukkan bahwa ada tigabelas pedagang pengecer, dimana dua pedagang pengecer menjual ke pasar Kotamobagu, dua pedagang pengecer menjual ke pasar Langowan, tiga pedagang pengecer menjual ke pasar Karombasan dan enam pedagang pengecer menjual ke pasar Bersehati.

4. Konsumen

Konsumen merupakan orang yang membeli kentang dari pedagang pengecer untuk dikonsumsi.

\section{Saluran Pemasaran Kentang di Desa Makaaruyen Kecamatan Modoinding}

Saluran pemasaran merupakan jalur dari lembaga-lembaga pemasaran yang mempunyai kegiatan menyalurkan barang dari produsen ke konsumen. Pola saluran pemasaran kentang dapat diketahui dengan cara mengikuti arus pemasaran kentang mulai dari petani sampai kepada kosumen. Berdasarkan penelitian yang telah dilaksanakan, dapat diketahui bahwa pola pemasaran kentang di Desa Makaaruyen Kecamatan Mododinding adalah sebagai berikut :

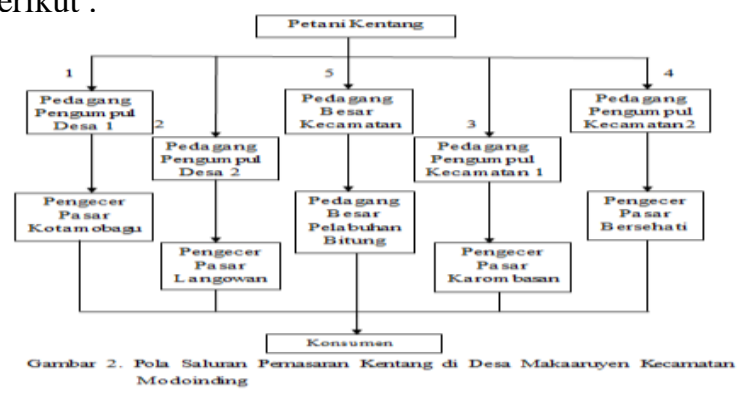

Hasil penelitian menunjukkan terdapat lima saluran pemasaran kentang dari Desa Makaaruyen Kecamatan Modoinding yaitu:

1. Saluran pemasaran I

Petani $\rightarrow$ Pedagang Pengumpul Desa $1 \rightarrow$ Pedagang Pengecer Kotamobagu $\rightarrow$ Konsumen

2. Saluran Pemasaran II

Petani $\rightarrow$ Pedagang Pengumpul Desa $2 \rightarrow$ Pedagang Pengecer Langowan $\rightarrow$ Konsumen

3. Saluran Pemasaran III

Petani $\rightarrow$ Pedagang Pengumpul Kecamatan $2 \rightarrow$ Pedagang Pengecer Bersehati $\rightarrow$ Konsumen

4. Saluran Pemasaran IV

Petani $\rightarrow$ Pedagang Pengumpul Kecamatan $3 \rightarrow$ Pedagang Pengecer Karombasan $\rightarrow$ Konsumen

5. Saluran Pemasaran V

Petani $\rightarrow$ Pedagang Besar Kecamatan $\rightarrow$ Pedagang Besar Pelabuhan Bitung

\section{Saluran Pemasaran I}

Proses mengalirnya barang dari produsen ke konsumen memerlukan biaya karena dengan adanya biaya pemasaran, maka suatu produk akan meningkat harganya. Besarnya biaya yang dikeluarkan oleh lembaga pemasaran pada saluran pemasaran I dapat dilihat pada Tabel 5.

Tabel 5. Komponen Biaya, Keuntungan, Marjin Pemasaran dan Share Kentang Pada Saluran Pemasaran I dari Pusat Produksi Desa Makaaruyen ke Pusat Konsumen Pasar Kotamobagu

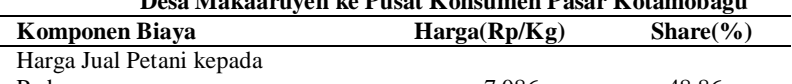

Pedagang $7.086 \quad 48,86$

Pengumpul Desa 1

Harga Jual Pedagang Pengumpul

Desa 1

Kepada Pedagang Pengecer Pasar

Kotamobagu

Biaya Pemasaran:

1. Pengemasan

2. Sortir dan Pengepakan

3. Pengangkutan

4. Bongkar Muat

5. Retribusi

Total Biaya

Keuntungan

Marjin Pemasaran

Harga Jual Pedagang Pengecer

kepada Konsumen

7. Pengemasan

8. Penyimpanan

9. Retribusi

Total Biaya

Keuntungan

Marjin Pemasaran

Total Biaya Pemasaran

Total Keuntungan

Total Marjin Pemasaran

Sumber : Data Primer yang Diolah, 2017

Tabel 5 menunjukkan bahwa total biaya pemasaran yang dikelurkan oleh pedagang pengumpul desa satu yaitu sebesar Rp. 675,02 atau 4,64 persen sedangkan total biaya yang dikeluarkan 
oleh pedagang pengecer yaitu sebesar Rp. 146,43 atau atau 1,01 persen. Hal ini disebabkan karena pedagang pengumpul desa satu menanggung biaya pengangkutan dari tingkat petani dan pedagang pengecer.Pedagang pengumpul desa satumembawa langsung kentang dari titik produksi sampai titik konsumen dipasar Kotamobagu. Pedagang pengumpul desa satu memperoleh keuntungan sebesar Rp. 1.239,98 atau 13,77 persen dan pedagang pengecer mendapatkan keuntungan sebesar Rp. 5.187 atau 35,77 persen. Keuntungan tertinggi diperoleh pedagang pengecer dengan margin pemasaran sebesar Rp. 5.500 atau 37,93 persen. Hal ini disebabkan karena pedagang pengecer tidak mengeluarkan biaya pengangkutan untuk transportasi.

\section{Saluran Pemasaran II}

Semakin panjang rantai pemasaran, maka biaya yang dikeluarkan akan semakin meningkat. Harga jual, harga beli dan biaya pemasaran akan menunjukkan besarnya keuntungan yang diperoleh setiap lembaga pemasaran dan akan berpengaruh terhadap marjin pemasaran. Besarnya biaya, keuntungan dan marjin pemasaran pada saluran pemasaran II dapat dilihat pada Tabel 6 .

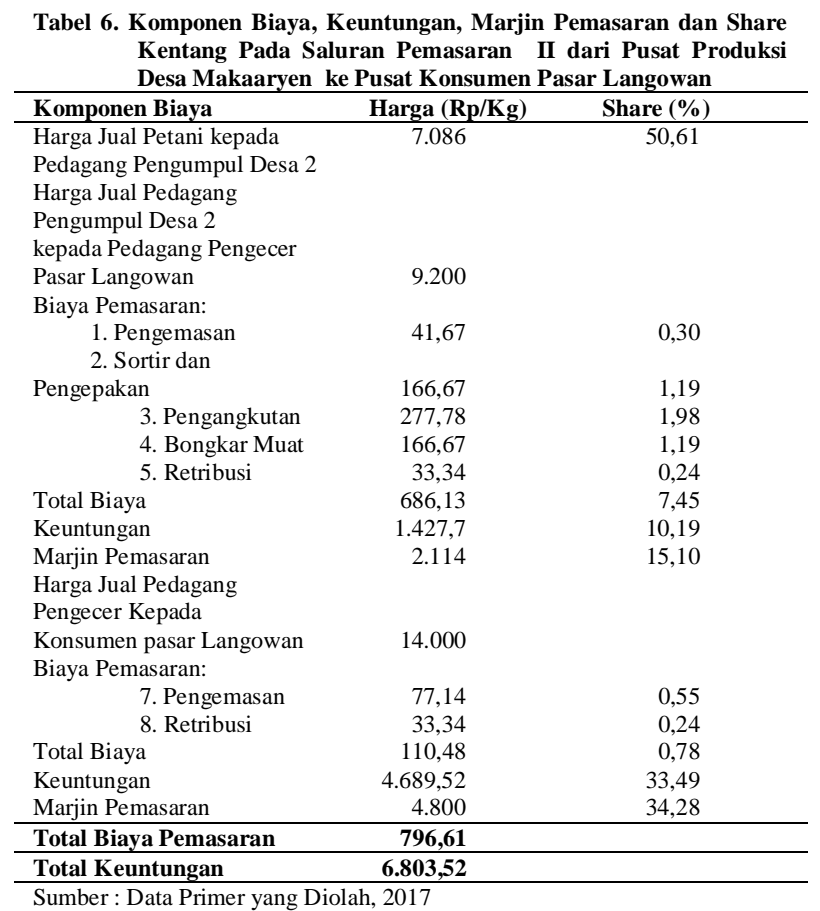

Tabel 6 menunjukkan bahwa total biaya yang dikeluarkan oleh pedagang pengumpul desa dualebih besar dibandingkan dengan pedagang pengecer yaitu sebesar Rp. 686,13 atau 7,45 persen sedangkan total biaya yang dikeluarkan oleh pedagang pengecer yaitu $\mathrm{Rp}$.
110,48 atau 0,78.Hal ini disebabkan karena pedagang pengumpul desa dua membawa langsung kentang dari Desa Makaaruyen sampai ke pasar Langowansebesar Rp. 1.636 atau 11,69 persen. Pedagang pengecer tidak mengeluarkan biaya pengangkutan untuk transportasi kentang sehingga mendapatkan keuntungan sebesar Rp. 4.689,52 atau 33,49 persen dengan margin pemasaran tertinggi yaitu Rp. 4.800 atau 34,28 sedangkan marjin pemasaran pedagang pengumpul memperoleh keuntungansebesar 10,19 Rp. 2.114 atau persen. Pengangkutan kentang dilakukan oleh pedagang pengumpul desa dua yaitu menggunakan mobil pick up milik pengumpul dengan muatan berbagai macam hasil lainnya seperti bawang, tomat, kol, pitsai dan wortel.

\section{Saluran Pemasaran III}

Besarnya biaya pemasaran yang harus dikeluarkan oleh setiap lembaga pemasaran serta keuntungan yang didapatkan akan berpengaruh terhadap marjn pemasaran. Besarnya biaya, keuntungan dan marjin pemasaran pada saluran pemasaran III dapat dilihat pada Tabel 7.

\begin{tabular}{|c|c|c|}
\hline Komponen Biaya & Harga $(\mathrm{Rp} / \mathrm{Kg})$ & Share $(\%)$ \\
\hline \multicolumn{3}{|l|}{ Harga Jual Petani ke } \\
\hline Pedagang & 7.160 & 46,70 \\
\hline \multicolumn{3}{|l|}{ Pengumpul Kecamatan 1} \\
\hline Haga Jual Pedagang & & \\
\hline $\begin{array}{l}\text { Pengumpul Kecamatan } 2 \\
\text { kepada Pedagang }\end{array}$ & & \\
\hline Pengecer Pasar Bersehati & 9.700 & \\
\hline 1. Pengemasan & 41,67 & 0,27 \\
\hline \multicolumn{3}{|l|}{ 2. Sortir dan } \\
\hline Pengepakan & 166,67 & 1.08 \\
\hline 3. Bongkar Muat & 166,67 & 1,08 \\
\hline 4. Pengangkutan & 312,5 & 2,04 \\
\hline 5. Retribusi & 50,00 & 0,33 \\
\hline Total Biaya & 737,51 & 4,81 \\
\hline Keuntungan & $1.802,49$ & 11,75 \\
\hline Marjin Pemasaran & 2.540 & 16,56 \\
\hline \multicolumn{3}{|l|}{ Harga Jual Pedagang } \\
\hline \multicolumn{3}{|l|}{ Pengecer } \\
\hline kepada Konsumen & 15.334 & \\
\hline \multicolumn{3}{|l|}{ Biaya Pemasaran } \\
\hline 6. Pengemasan & 71,42 & 0,47 \\
\hline 7. Retribusi & 50,00 & 0,33 \\
\hline Total Biaya & 121,42 & 0,79 \\
\hline Keuntungan & $5.512,58$ & 35,95 \\
\hline Marjin Pemasaran & 5.634 & 36,74 \\
\hline \multicolumn{3}{|l|}{ Total Biaya Pemasaran } \\
\hline Total Keuntungan & $7.315,07$ & \\
\hline Total Marjin Pemasaran & 8.174 & \\
\hline
\end{tabular}

Tabel 7 menunjukkan bahwa total biaya pemasaran ditingkatpedagang pengumpul kecamatan satu adalah Rp. 737,51 atau 4,81 persen sedangkan total biaya yang dikeluarkan oleh pedagang pengecer pasar Bersehati yaitu Rp. 121,42 atau 0,79 persen. Perbedaan total biaya yang cukup besar antara pengumpul dan pengecer, disebabkan oleh 
biaya pengangkutan untuk transportasi kentang kepasar yang ditanggung pengumpul, lebih besar karena jarak yang lebih jauh. Keuntungan yang diperoleh pengumpul kecamatan yaitu sebesar Rp. $1.802,49$ atau 11,75 dan pedagang pengecer mendapatkan keuntungan sebesar Rp. 5.512,58 atau 35,95 persen. Pengecer hanya mengeluarkan biaya pengemasan dan biaya retribusi sehingga keuntungan yang diperoleh jauh lebih besar dari pedagang pengumpul kecamatan. Marjin pemasaran tertinggi berada ditingkat pedagang pengecer yaitu Rp. 5.634 atau 36,74 persen.

\section{Saluran Pemasaran IV}

Proses mengalirnya barang dari produsen ke konsumen memerlukan biaya karena dengan adanya biaya pemasaran, maka suatu produk akan meningkat harganya. Semakin panjang rantai pemasaran, maka biaya yang dikeluarkan akan semakin meningkat. Besarnya biaya yang dikeluarkan oleh lembaga pemasaran pada saluran pemasaran IV dapat dilihat pada Tabel 8.

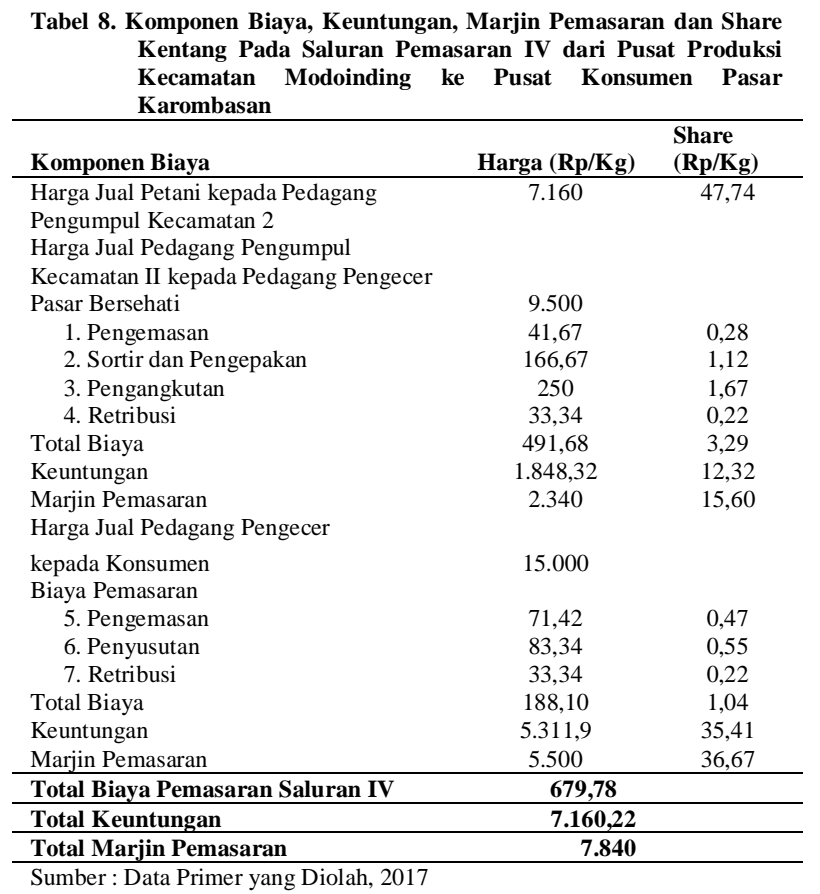

Tabel 8 menunjukkan bahwa share yang diterima petani adalah 47,74 persen. Total biaya yang dikeluarkan oleh pedagang pengumpul kecamatan duayaitu sebesar Rp. 491,6 atau 3,29 persen sedangkan total biaya yang dikeluarkan yang dikeluarkan pengecer yaitu Rp. 188,10 atau 1,04 persen. Hal ini disebabkan karena jarak membawa kentang dari produsen ke konsumen akhir lebih jauh, sehingga biaya pengangkutan yang dikeluarkan cukup besar. Sedangkan keuntungan terbesar diperoleh tingkat pedagang pengecer yaitu sebesar Rp. 5.312 atau 35,41 persen dengan marjin pemasaran Rp. 7.840 atau 52,27 persen.

\section{Saluran Pemasaran V}

Perbedaan besarnya biaya pemasaran yang harus dikeluarkan oleh lembaga-lembaga pemasaran akan menyebabkan perbedaan harga, karena masingmasing berusaha untuk memperoleh keuntungan dari proses pemasaran tersebut.. Harga jual, harga beli dan biaya pemasaran akan menunjukkan besarnya keuntungan yang diperoleh setiap lembaga pemasaran dan akan berpengaruh terhadap marjin pemasaran. Besarnya biaya, keuntungan dan marjin pemasaran pada saluran pemasaran $\mathrm{V}$ dapat dilihat pada Tabel 9.

\begin{tabular}{lcc}
\hline $\begin{array}{l}\text { Tabel 9. Komponen Biaya, Keuntungan, Marjin Pemasaran dan } \\
\text { Share Kentang Pada Saluran Pemasaran V dari Pusat } \\
\text { Produksi Kecamatan Modoinding ke Pusat Pelabuhan di } \\
\text { Bitung }\end{array}$ & \\
\hline & Harga (Rp/Kg) & Share (\%) \\
\hline Komponen Biaya & 6.696 & 72,78 \\
\hline Harga Jual Petani kepada & & \\
Pedagang & & \\
Besar Kecamatan & 9.200 & \\
Harga Jual Pedagang Besar & & \\
Kecamatan kepada Pedagang & & \\
Besar di Pelabuhan Bitung & 66,67 & 0,72 \\
Biaya Pemasaran & 58,34 & 0,63 \\
1. Pengemasan & 166,67 & 1,81 \\
2. Sortir & 30,00 & 0,32 \\
3. Pengepakan & 375 & 4,07 \\
4. Pengangkutan 1 & 166,67 & 1,81 \\
5. Pengangkutan 2 & $\mathbf{8 6 3 , 3 5}$ & $\mathbf{9 , 3 8}$ \\
6. Bongkar Muat & $\mathbf{1 . 6 4 0 , 6 5}$ & $\mathbf{1 7 , 8 3}$ \\
\hline Total Biaya & $\mathbf{2 . 5 0 4}$ & $\mathbf{2 2 , 2 1}$ \\
\hline Keuntungan & & \\
\hline Marjin Pemasaran &
\end{tabular}

Tabel 9 menunjukkan bahwa total biaya yang dikeluarkan oleh pedagang besar kecamatan yaitu sebesar Rp. 863,35 atau 9,38 persen. Pedagang besar kecamatan tiga mengeluarkan biaya yang besar karena jarak dari titik produsen ke titik konsumen cukup jauh sehingga, proses pengangkutanyang dilakukan yaitu sebanyak dua kali dengan biaya transportsi yang besar.Total keuntungan yang diperoleh pedagang besar kecamatan tiga yaitu Rp. 1.640,65 atau 17,83 persen. Dengan marjin pemasaran Rp. 2.504 atau 9,38 persen.

\section{Farmer's Share}

Farmer's share merupakan perbandingan antara harga yang diterima oleh petani kentang dengan harga yang dibayarkan oleh konsumen akhir. Menurut Widiyanti (2008), besarnya farmer's share akan mempengaruhi nilai marjin pemasaran dan semakin banyak lembaga pemasaran yang terlibat dalam saluran pemasaran maka akan mempengaruhi farmer's share. Nilai farmer's share pada setiap saluran pemasaran yang terbentuk dari kegiatan pemasaran kentang, dapat dilihat pada Tabel 10. 
Tabel 10. Farmer's Share pada Saluran Pemasaran Kentang dari Desa Makaaruyen Kecamatan Modoinding

\begin{tabular}{llccc}
\multicolumn{5}{c}{ dari Desa } \\
No & $\begin{array}{l}\text { Saluran } \\
\text { Pemasaran }\end{array}$ & $\begin{array}{c}\text { Harga di } \\
\text { Tingkat } \\
\text { Petani } \\
(\mathbf{R p} / \mathbf{K g})\end{array}$ & $\begin{array}{c}\text { Harga di } \\
\text { Tingkat } \\
\text { Konsumen } \\
(\mathbf{R p} / \mathbf{K g})\end{array}$ & $\begin{array}{c}\text { Farmer's } \\
\text { Share } \\
(\boldsymbol{\%})\end{array}$ \\
\hline 1 & Saluran I & 7.086 & 14.500 & 48,86 \\
2 & Saluran II & 7.086 & 14.000 & 50,61 \\
3 & Saluran III & 7.160 & 15.334 & 46,70 \\
4 & Saluran IV & 7.160 & 15.000 & 47,74 \\
5 & Saluran V & 7.160 & 18.000 & 39,78 \\
\hline \multicolumn{5}{l}{ Sumber : Data Primer yang Diolah, 2017 }
\end{tabular}

Tabel 10 menunjukkan bahwa nilai farmer's share tertinggi berada pada saluran pemasaran dua yaitu sebesar 50,61 persen karena harga yang diterima petani cukup tinggi sehingga sesuai dengan biaya yang dikeluarkan. Sedangkan farmer's share terendah diperoleh saluran pemasaran lima. Hal ini disebabkan karena harga yang diterima petani rendah akibat keterkaitan modal yang dimilki kepada pedagang besar kecamatan sehingga petani siap menerima harga pasar yang ditentukan oleh pedagang besar.

Tabel 11. Efisiensi Pemasaran pada Saluran Pemasaran Kentang

\begin{tabular}{|c|c|c|c|c|c|}
\hline No & $\begin{array}{l}\text { Saluran } \\
\text { Pemasaran }\end{array}$ & $\begin{array}{c}\text { Total } \\
\text { Biaya } \\
\text { Pemasaran } \\
(\mathbf{R p} / \mathbf{K g})\end{array}$ & $\begin{array}{c}\text { Total } \\
\text { Keuntungan } \\
\text { Pemasaran } \\
(\mathbf{R p} / \mathbf{K g})\end{array}$ & $\begin{array}{c}\text { Total } \\
\text { Marjin } \\
\text { Pemasar } \\
\text { an } \\
(\mathbf{R p} / \mathbf{K g}) \\
\end{array}$ & $\begin{array}{c}\text { Farmer's } \\
\text { Share } \\
(\%)\end{array}$ \\
\hline 1 & Saluran I & 821,45 & $6.426,98$ & 7.414 & 48,86 \\
\hline 2 & Saluran II & 796,61 & $6.803,52$ & 6.914 & 50,61 \\
\hline 3 & Saluran III & 858,93 & $7.315,07$ & 8.174 & 46,70 \\
\hline 4 & Saluran IV & 679,78 & $7.160,22$ & 7.840 & 47,74 \\
\hline 5 & Saluran V & 863,35 & $1.640,65$ & 2.504 & 39,78 \\
\hline
\end{tabular}

Tabel 11 menunjukkan bahwa untuk efisiensi pemasaran kentang yang baik adalah saluran pemasaran dua dengan total biaya pemasaran Rp. 796,61 dan keuntungan sebesar Rp 6.803,52. Marjin pemasaran terendah yaitu Rp. 6.914 dan nilai farmer'share tertinggi yaitu Rp. 50,61.

\section{KESIMPULAN DAN SARAN}

\section{Kesimpulan}

Hasil penelitian menunjukkan bahwa terdapat lima saluran pemasaran di Desa Makaaruyen Kecamatan Modoinding yaitu:

1) Saluran pemasaran pertama terjadi dari Desa Makaaruyen sampai ke pasar Kotamobagu

2) saluran pemasaran kedua yaitu dari Desa Makaruyen sampai ke pasar Langowan, saluran pemasaran tiga terbentu dari Desa Makaaruyen sampai ke Pasar Bersehati

3) Saluran pemasaran empat terjadi dari desa Makaaruyen sampai ke pasar Karombasan dan
4) Saluran pemasaran lima terjadi dari desa Makaaruyen sampai ke pedagang besar pelabuhan Bitung.

Saluran pemasaran dua merupakan saluran yang baik untuk digunakan, karena marjin pemasarannya mermiliki nilai terendah dan nilai farmer's share yang diperoleh adalah tertinggi dibandingkan dengan saluran pemasaran lain yang terbentuk.

\section{DAFTAR PUSTAKA}

Aeni, E. 20013. Tataniaga Kentang di Desa Sangiang Kecamatan Banjaran Kabupaten Majalengka, Jawa Barat. Bogor: Institut Pertanian Bogor. Diakses tanggal 5 Mei 2015.

Agustnia dan Mayrowani H, 2008. Pola Distribusi Komoditas Kentang di Kabupaten Bandung, Jawa Barat. Jurnal Ekonomi Pembangunan.

Fred D, 2009.Konsep Manajemen Strategis. Jakarta.

Hasibuan M, 2011. Manajemen Sumber Daya Manusia. Jakarta.

Hastuti R, 2005. Sistem Manajemen Agribisnis. Makasar.

Kotler P, 2009. Manajemen Pemasaran. Jilid ke-2. Bob Sabian, Penerjemah. Jakarta (ID): Erlangga. Terjemahan dari: Marketing Manajemen. Ed ke-13.

Maulia S, 2012. Analisis Pendapatan Usaha Tani dan Faktor-Faktor Yang Mempengaruhi Produktivitas Kentang di Desa Cigedug, Kecamatan Cigedug.

Mulyadi, 2005. Akuntansi Biaya. Edisi Kelima. Yogyakarta: UPPAMP Universitas Gajah Mada.

Musa H, 2014. Manajemen Pemasaran: Suatu Pendekatan Analisis. Yogyakarta: BPFE Kabupaten Garut [Skripsi]. Bogor (ID. Institut Pertanian Bogor.

Nadhawatunnaja, N. 2008.Analisi Pendapatan Usahatani dan Faktor-Faktor Yang Mempengaruhi Produksi Paprika Hidrolik di Desa Pasir Langu, Kecamatan Cisarua, Kabupaten Bandung. Jurnal Manajemen Agribisnis: IPB. Diakses tanggal 19 September 2016. 
Nurulita F, 2011. Analisis Pemasaran Kentang (Solanum Tubersom L) di Kabupaten Wonosobo.Skripsi. Fakultas Pertanian. UNS. Solo.

Rosmawati, H. 2011. Analisis Efisiensi Pemasaran Pisang Produksi Petani di Kecamatan Lengkiti Kabupaten Ogan Komering Ulu.Agronobis. Vol. 3, No.5, Maret 2017

Setiadi, 2009.Budi Daya Kentang.Jakarta (ID) : Swadaya.

Simamora B, 2005. Analisis Multivarit Pemasaran. Jakarta : Gramedia.

Soekartawi, 2002.Prinsip Dasar Manajemen Pemasaran Hail-hasil Pertanian.PT.Raja Grafindo Persada. Jakarta.
Swastha B, 2000. Manajemen Pemasaran Modern.Liberty.Yogyakarta.

Thomas H, 2012. Tesis Sistem Manajemen Lembaga Pemasaran Komoditi Sayuran Wortel (Daucus Carota L) di Kelurahan Rurukan Kecamatan Tomohon Timur.Program Pascasarjana Universitas Sam Ratulangi Manado.

Tjiptono, F. 2008. Strategi Pemasaran.Edisi 3. Andi: Yogyakarta.

Widayanti, S. 2008. Analisis Efisiensi Pemasaran Talas Di Kecamatan Taman Sari, Kabupaten Bogor, Jawa Barat (Skripsi). IPB. 